\title{
Industrial Buyer Innovation Adoption Model: A Focus on a Smartphone-Based Electrochemical Analytical Device for Toxic Heavy Metal Detection
}

\author{
Wasapon Thanabodypath ${ }^{1}\left(\mathbb{D}\right.$, Achara Chandrachai ${ }^{2}$, Sudkate Chaiyo ${ }^{3}(\mathbb{D})$ and Orawon Chailapakul ${ }^{4, *}$ \\ 1 Technopreneurship and Innovation Management Program, Graduate School, Chulalongkorn University, \\ Bangkok 10330, Thailand; wasapon@gmail.com \\ 2 Chulalongkorn Business School, Chulalongkorn University, Bangkok 10330, Thailand; \\ achandrachai@gmail.com \\ 3 Institute of Biotechnology and Genetic Engineering, Chulalongkorn University, Bangkok 10330, Thailand; \\ sudkate.c@chula.ac.th \\ 4 Electrochemistry and Optical Spectroscopy Center of Excellence (EOSCE), Department of Chemistry, \\ Faculty of Science, Chulalongkorn University, Bangkok 10330, Thailand \\ * Correspondence: corawon@chula.ac.th
}

check for updates

Citation: Thanabodypath, W.; Chandrachai, A.; Chaiyo, S.; Chailapakul, O. Industrial Buyer Innovation Adoption Model: A Focus on a Smartphone-Based

Electrochemical Analytical Device for Toxic Heavy Metal Detection. Sustainability 2021, 13, 11718. https:// doi.org/10.3390/su132111718

Academic Editor: Barbara Motyl

Received: 8 September 2021

Accepted: 20 October 2021

Published: 23 October 2021

Publisher's Note: MDPI stays neutral with regard to jurisdictional claims in published maps and institutional affiliations.

Copyright: (c) 2021 by the authors. Licensee MDPI, Basel, Switzerland. This article is an open access article distributed under the terms and conditions of the Creative Commons Attribution (CC BY) license (https:/ / creativecommons.org/licenses/by/ $4.0 /)$.

\begin{abstract}
Smartphone-Based Electrochemical Analytical Devices (SEAD) enable sophisticated toxic heavy metal quantification experiments to be conducted anywhere with high precision, selectivity, and sensitivity. However, a very limited number of such technologies are able to make the transition from the lab to the competitive B2B marketplace. The purpose of this paper is to examine the factors influencing SEAD adoption in the manufacturing industry using the Industrial Buyer Innovation Adoption (IBIA) model, which integrates B2B consumer behavior theories and technology acceptance models from the past 50 years. Analysis of data collected from 400 corporations in Thailand revealed that sellers, buyers, internal organization and invented technology advantage variables predicted industrial innovation adoption based on binary logistic regression. This research contributes to the understanding of SEAD transition from scientific knowledge to sustainable technology and diffusible innovation. The ambitious IBIA framework is potentially an alternative managerial tool for holistically assessing and creating adoptable innovative business models for new technologies.
\end{abstract}

Keywords: innovation adoption model; portable electrochemical analytical devices; predicting technology adoption; industrial consumer behavior; industrial contaminants

\section{Introduction}

Toxic heavy metals pose a threat to the three pillars of sustainability, which are the society, the economy and the environment, costing medical expenses up to 977 billion USD annually in low to middle-income countries across the world [1]. In the past decade, there have been around 18,000 heavy metal poisoning cases per year in Thailand [2]. The main sources of heavy metal contaminants are industrial waste, paints, mining, fuels, drinking water, packaging and cosmetics [3]. Although heavy metal contamination is monitored in the industrial sector, it is inspected infrequently and stochastically under industrial regulations and legal requirements due to the complexity and expense of testing procedures such as Inductive Coupled Plasma Atomic Emission Spectrometry (ICP-AES) and Atomic Absorption Spectroscopy (AAS). As a result, heavy metals such as lead, mercury, cadmium, chromium and arsenic leak into the environment, causing serious health problems such as fatigue, gastrointestinal tract diseases, dementia, encephalopathy and cancer. Accurate heavy metal sensors integrated with smartphone technology are a potential solution, offering portability and adoptability at lower costs. This is a current area of development, with the heavy metal testing market expanding $7 \%$ annually and expected to reach 3.65 billion USD by 2022 [4]. 
Powerful Smartphone-Based Electrochemical Analytical Devices (SEAD) allow users to conduct complex electrochemical experiments in different locations. Technological development has also been considered a sub-domain of sustainable development [5] as science, technology and innovation improve economic growth and social well-being [6,7]. SEAD innovation is targeted to support sustainable digital transitions of our economy and society for monitoring contaminated water, which is aligned with the European Commission's Chemicals Strategy for Sustainability Towards a Toxic-Free Environment [8]. Despite the considerable hype among researchers about SEADs' advantages, a very limited number of such technologies could make the transition from the lab to the competitive B2B marketplace due to technological, economic and regulatory limitations [9-12]. Thus, determinants of consumer buying behavior and technology adoption play a pivotal role in understanding the innovation adoption process for this particular technology. The Industrial Buyer Innovation Adoption (IBIA) model can be used to validate and forecast the adoption of SEAD for heavy metal detection in the manufacturing industry. The model integrates $\mathrm{B} 2 \mathrm{~B}$ consumer behavior theories and technology acceptance models from the past 50 years (1971-2020).

This paper is organized as follows: Section 2 scrutinizes the background of SEAD for heavy metal detection, and reviews literature on $\mathrm{B} 2 \mathrm{~B}$ consumer behavior theories and technology acceptance models. Section 3 introduces the research model and hypotheses. Research methodology is outlined in Section 4. Section 5 analyzes data and findings. Section 6 discusses results. Finally, conclusions and future perspectives are presented in Section 7.

\section{Theoretical Background}

\subsection{Smartphone-Based Electrochemical Analytical Devices for Heavy Metal Detection (SEAD)}

Various SEAD applications have been developed [13] such as point-of-care testing (e.g., glucometer), physiological signal tracking (e.g., electrocardiogram), energy storage supercapacitors, and environmental monitoring. This study focuses on SEAD for environmental toxic heavy metal detection. Its current development status according to Technology Readiness Levels [14] is at TRL 7. The system prototype is demonstrated in a real environment. For example, Li et al. [15] successfully utilized SEAD to analyze iron, nickel, chromium, copper and zinc in Hubin Lake. Moreover, SEADs were demonstrated to quantify mercury in Pearl river samples (Guangzhou, China) [16] and lead in Iranian water sources [17]. Their SEAD detection ranges achieved US EPA and WHO permissible safety standards for contaminants in water. SEADs (Figure 1) consist of 3 major components: (1) an electrochemical sensor, (2) a wireless potentiostat, and (3) smartphone communication and connection technology.

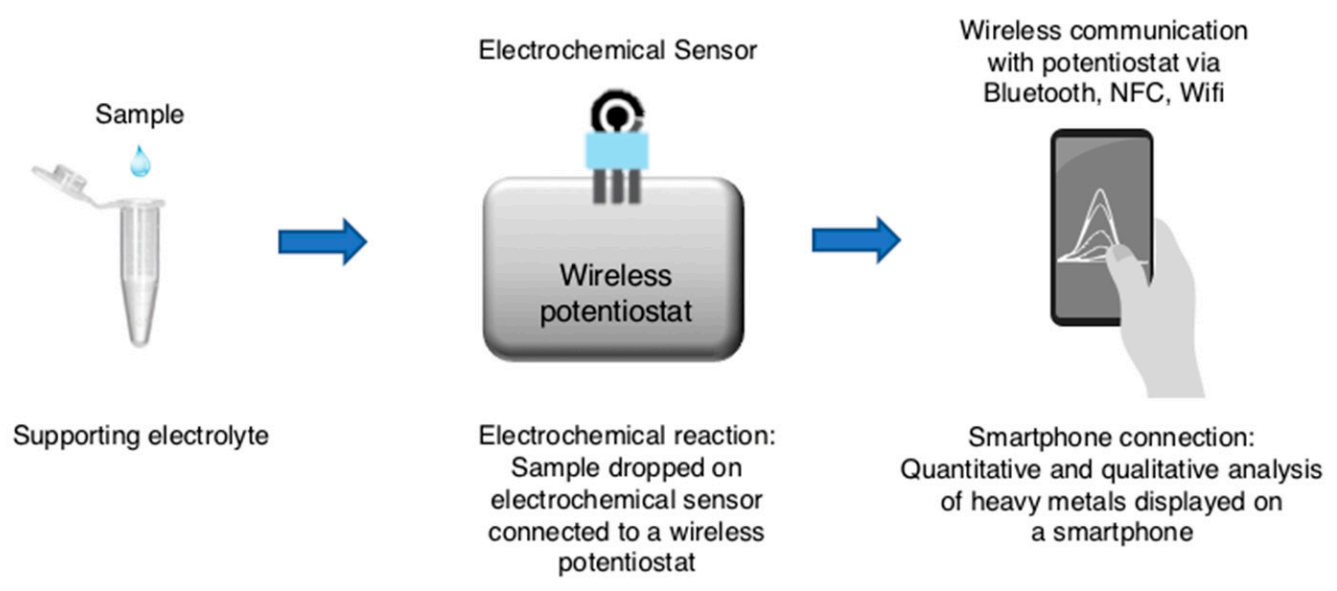

Figure 1. Smartphone-Based Electrochemical Analytical Device System. 
The electrochemical sensors are fabricated and modified by nanomaterials to detect specific heavy metal ions from redox reactions, involving electrons transferred between electrodes in an electrolyte [18,19], and are remarkable for their high precision, selectivity, and sensitivity. Electrochemical sensors make sophisticated laboratory experiments simple, rapid, economical, portable, and user-friendly. This is because they only require microvolumes of samples to work, and have low production costs [20,21]. Development techniques for electrochemical sensors depend on the modification of electrodes (i.e., reference electrode, working electrode, and auxiliary electrode). The electrodes are modified by composite materials for a higher sensitivity to intermolecular electron transfer, deposit, and distinguish (selectivity) measurable elements in the electrochemical cell with voltammetric techniques (e.g., cyclic voltammetry, differential pulse voltammetry, square wave voltammetry) [22]. In juxtaposition to results obtained from ICP-AES, the quantification of heavy metals using electrochemical sensors is also accurate and reliable [23-25].

A potentiostat is a voltage control measuring current flow between electrodes in an electrochemical cell [26]. These electrochemistry-based analytical instruments are widely used in research and science laboratories. The development of compact and wireless potentiostats allows connection with smartphones, making commercial technology adoption and market penetration more feasible. Portable potentiostats are simple to use, affordable at under 80 USD [27], and comparable to conventional bulky electrochemical workstations in terms of accuracy and reliability [28-30].

Smartphone communication and connection technologies are used to connect and control potentiostats with smartphone software. The wireless technologies equipped in most smartphones are Wi-Fi, Bluetooth, and Near Field Communication (NFC). Wi-Fi and Bluetooth can communicate from 100-500 m, but the paired devices require power from additional batteries [31,32]. NFC is based on Radio-Frequency Identification (RFID) protocol, allowing communication within $10 \mathrm{~cm}$ of a smartphone, and it passively and electromagnetically draws power from a tagged smartphone. All three devices (electrochemical sensors, potentiostats and smartphones) have to be connected and work together to detect heavy metals.

Our work takes a first step toward closing the gap in the real-world applications from research to commercialization of SEAD in volatile high-tech markets. Previous studies concerning SEAD components were fragmented in proof-of-concept and technological improvement purposes. To gain a widespread application and achieve a commercial success, electrochemical sensors and their systems need to overcome analytical performance, usability, regulatory, affordability and mass production feasibility issues [9-12,33]. Studies on similar SEAD components and systems also revealed that endogenous and exogenous factors impact adoption decisions. To illustrate this, RFID adoption in the supply chain management of the manufacturing industry negatively depended on the information intensity [34]. Information-intensive technologies are more difficult to deploy and diffuse since they require more supporting evidence and complex data processing. Similarly, the external factors including economic, quality assurance, and regulatory issues did not only intervene in adoption decisions, but technological and internal people were also barriers to the clinical adoption of advanced sensors and biomarker technologies used in point-of-care testing (POCT) devices. User errors resulted in an adverse impact. The effective adoption failed due to inappropriate storage of reagents and the incorrect collection of specimens [35]. POCT devices were rejected when the value proposition of new technologies was ambiguous to decision-makers [36].

\subsection{B2B Consumer Behavior Theories}

Consumer behavior theory is based on the study of decision-making processes and motivations of individual buyers, groups and organizations in choosing, purchasing and using products or services. The buying process consists of 3 steps: (1) inputs (price, quality, service, options) communicated to the target audience through various channels; (2) buyers' decision-making processes, expressed as (3) an outcome or purchasing decision [37]. 
Consumer behavior is related to acquisition, consumption, use, product, service, time, and the decision-maker's mindset. These behaviors are influenced by individuals and culture $[38,39]$. The consumer market is different from the business market as organizational decision journeys engage both internal and external influencers [40,41].

"A General Model for Understanding Organizational Buying Behavior" [42] is also a decision-making process starting from the need to use the product or service, then identifying and evaluating candidates, and finally making a purchase. The process involves the environment, the organization, sellers, and individual participants who play different roles as users, influencers, decision-makers, buyers and gatekeepers. Sheth [43] and Johnston \& Lewin [44] proposed integrative models of industrial buying behavior, adding expectations, perceptions and relationships between buyers and sellers in the market. In summary, B2B consumer behavior is a process following Kotler's buying pattern of input, process and output.

Nonetheless, available theoretical generic models from previous studies may not be fully applicable to analyzing buyer's decisions in new and complex technology markets as new technologies come with high risks. Performance and user experience information are still being holistically evaluated [45]. An empirical study on the industrial consumer decision-making behavior in the portable heavy metal analyzer market is missing from previous innovation adoption research. Therefore, it is necessary to adapt these models in order to analyze the adoption of this distinct SEAD technology.

\subsection{Technology Acceptance Models (TAM)}

The diffusion of innovation at the organizational level is affected by individual variables (attitude toward change), internal characteristics (centralization, complexity, formalization, interconnectedness, organizational slack and size), and external characteristics (system openness) [46]. Technological adoption is a process of problem-solving, from idea generation to implementation [47]. To attain technology acceptance, it is essential for technology developers and consumers to communicate and work together as suggested in the innovation coupling model [48], starting from the idea generation stage, research design and development, prototype, manufacturing, and marketing.

Davis' TAM [49] is based on the Theory of Reasoned Action (TRA) [50], which aims to explain the relationship between attitudes and behaviors. TRA and the Theory of Planned Behavior (TPB) [51] focus on personal and social beliefs, but do not consider technological aspects, as observed in Davis' TAM. Technology adoption results from four factors, which are (1) external variables affecting attitudes (e.g., social influence, age and gender), (2) perceived usefulness and perceived ease of use (i.e., improved efficiency and convenience), (3) attitude towards using, and (4) behavioral intention to use that leads to actual technology adoption. TAM has been developed into further variations. For instance, external and user variables (e.g., experience, subjective norm, output quality) were added to TAM 2 [52]. The effects of trust and perceived risk were included in TAM 3 for better suitability to the e-commerce context [53]. TAM has to be redefined to analyze new technologies as user characteristics always change over time. The perceived usefulness and perceived ease of use lack of heuristic value, preventing it from describing external determinants, especially economics, society, technology infrastructure and natural environment factors that tremendously intervene SEAD adoption decisions.

The Technology-Organization-Environment (TOE) Framework [54] also describes technology adoption as a process starting from (1) an accepted new paradigm from research and publications, (2) a market feasible prototype, (3) technology acceptance and purchase, (4) actual use of technology, to (5) repeat purchase. TOE Framework consists of 3 contexts: (1) technology (e.g., competitiveness, complexity, compatibility); (2) organization (e.g., size, structure, communication); and (3) environment (market characteristics, technology infrastructure, regulations). TOE Framework has to be adapted to suit the studied technology. For example, to study RFID adoption, Wang et al. [34], modified the TOE Framework with additional sub-contexts including technology competence [55], top management 
support [56], and external environment pressure [57-59]. TOE evaluates environmental impacts, but its organizational factors are generic. Industrial organizations are complex and comprised of hierarchical levels. To contextualize our knowledge of SEAD adoption, both internal organization and internal people characteristics must be investigated.

An integrated model, Unified Theory of Acceptance and Use of Technology (UTAUT) [60] was developed by combining variables from eight technology acceptance models, which are TRA [50], TAM [49], the motivational model [61], TPB [51], a model of personal computer use [62], the diffusion of innovations theory [63], combined TAM \& TPB [64] and social cognitive theory [65]. Bagozzi [66], Van Raaij \& Schepers [67], and Li [68] criticized the practicality and theoretical foundations of UTAUT. Although the model analyzes intent, behavior, and technology application from four behavioral factors: (1) performance expectation, (2) effort expectation, (3) social influence, and (4) adoption environment (e.g., organizational structure and technology infrastructure), the considered factors (i.e., sex, age, experience and voluntary use) are more suitable for the explanation of B2C rather than B2B product and service acceptance. UTAUT is not suitable for SEAD as we focus on B2B market adoption.

It is clear that TAMs, TOE, UTAUT have limitations and cannot be used to describe all technology adoption phenomena. The adoption of SEAD for heavy metal detection has not been directly investigated. There is only tangential evidence available from studies on related technologies. Electrochemical analytical devices have not achieved commercial success because of their lack of convenience, portability, cost, mass production feasibility and consumer acceptance, while regulations provide a further obstacle to manufacturers [9-12,33]. Additionally, each organization and industry values technologies differently. Seo et al. [69] suggest that the convergence of smartphones and nanotechnologies will improve quality of life by monitoring hazardous chemicals. In short, there is no empirical evidence that precisely delineates the adoption of SEAD for heavy metal detection among sellers and buyers.

\section{Research Model and Hypotheses}

The basis of the industrial buyer innovation adoption (IBIA) framework is the synergy of B2B consumer behavior theories and TAM models. It is a systematic framework for quantitative integration of industrial user's behavioral motivations to understand and predict the adoption of SEAD innovation during the decision-making processes. This study focuses on identifying factors that can predict a binary dependent variable (adopter or non-adopter). To examine industrial consumer technological adoption, IBIA framework is proposed, as shown in Figure 2. The model consists of a 3-stage process and 6 determinants with 24 measurement items that are hypothesized to have direct effects on industrial adoption of SEAD technology for heavy metal detection. Determinants and measurement items are derived from existing industrial consumer behavior and technology acceptance literature over the past 50 years (Table 1 and Appendix A). Innovation adoption problems are identified and reflected as input in the first stage of market interactions. IBIA framework combines collected data from communications among influencing groups of seller and buyer determinants. In the second stage, potential adopters explore solutions from the technology acceptance processes that involve the assessment of internal, external and technological factors related to SEAD. The final stage is the response to SEAD innovation. 


\section{Input}

Problem Identification and

Marketplace Interactions

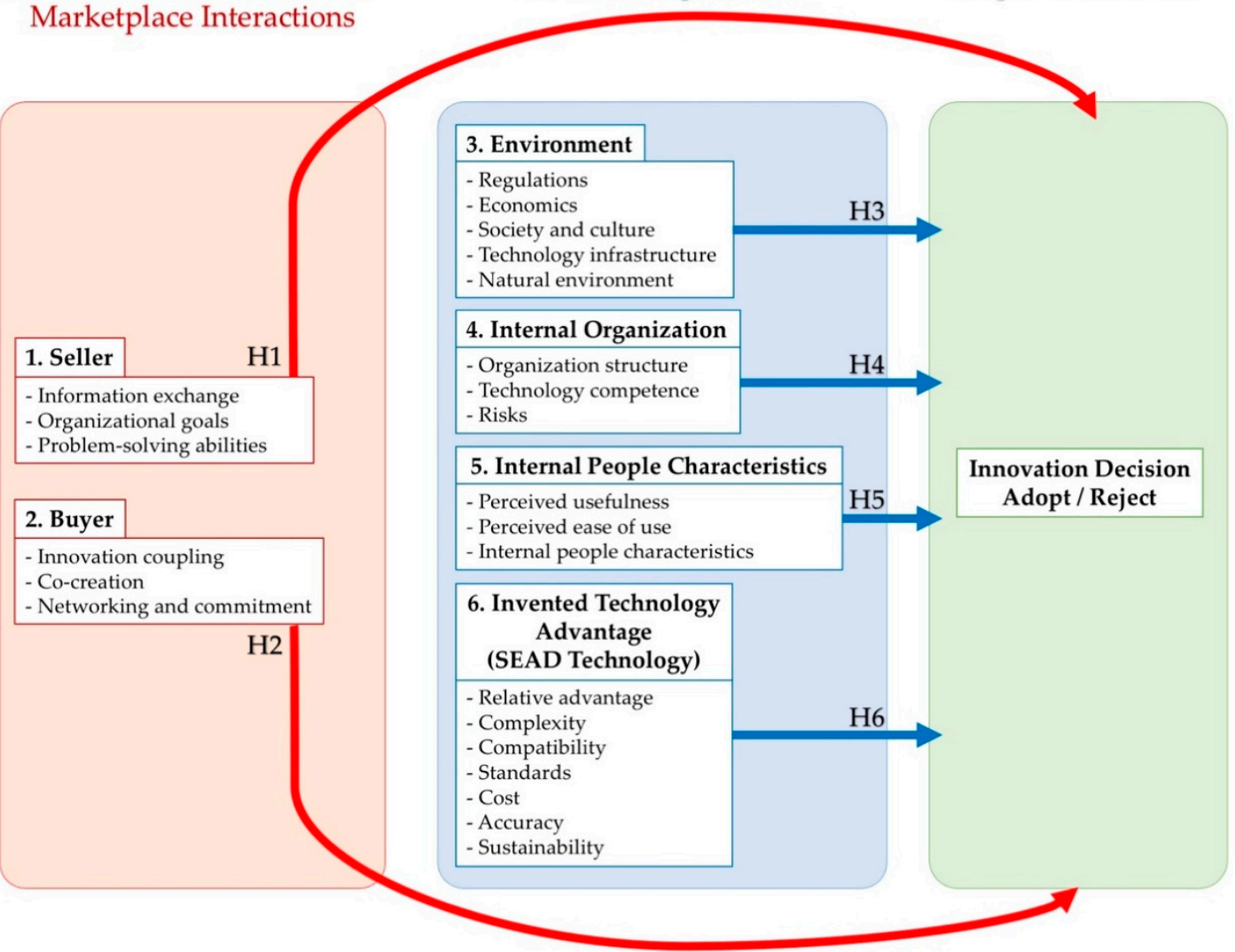

Output

Process

Solution Exploration
Response \& Result

Figure 2. Industrial Buyer Innovation Adoption Model (IBIA).

Table 1. Measurement items of independent variables.

\begin{tabular}{|c|c|c|c|}
\hline Adoption Process & $\begin{array}{c}\text { Independent } \\
\text { Variables (Determinants) }\end{array}$ & Measurement Items & References \\
\hline \multirow{2}{*}{$\begin{array}{c}\text { Input } \\
\text { (Problem identification in } \\
\text { the marketplace) }\end{array}$} & Seller & $\begin{array}{l}\text { Information exchange } \\
\text { Organizational goals } \\
\text { Problem-solving abilities }\end{array}$ & $\begin{array}{c}{[42-44,46,70-72]} \\
{[41-44,47,73-75]} \\
{[41,43,47,74,76,77]}\end{array}$ \\
\hline & Buyer & $\begin{array}{c}\text { Innovation coupling } \\
\text { Co-creation } \\
\text { Networking and commitment }\end{array}$ & $\begin{array}{c}{[48,78]} \\
{[40,44,79,80]} \\
{[80-83]}\end{array}$ \\
\hline \multirow{4}{*}{$\begin{array}{l}\text { Technology acceptance processes } \\
\text { (Solution exploration) }\end{array}$} & Environment & $\begin{array}{c}\text { Regulations } \\
\text { Economics } \\
\text { Society and culture } \\
\text { Technology infrastructure } \\
\text { Natural environment }\end{array}$ & $\begin{array}{c}{[42-44,84-86]} \\
{[42-44,74,87]} \\
{[42-44,47,51,60,88]} \\
{[42-44,47,74]} \\
{[42-44,89]}\end{array}$ \\
\hline & Internal Organization & $\begin{array}{c}\text { Organizational structure } \\
\text { Technology competency } \\
\text { Risks }\end{array}$ & $\begin{array}{c}{[44,46,54,90]} \\
{[42,55]} \\
{[86,91]}\end{array}$ \\
\hline & Internal people characteristics & $\begin{array}{c}\text { Perceived usefulness } \\
\text { Perceived ease of use } \\
\text { Internal people characteristics }\end{array}$ & $\begin{array}{c}{[52,88]} \\
{[52,88]} \\
{[42-44,50,51,60,92]}\end{array}$ \\
\hline & $\begin{array}{l}\text { Invented technology } \\
\text { advantage (SEAD) }\end{array}$ & $\begin{array}{c}\text { Relative advantage } \\
\text { Complexity } \\
\text { Compatibility } \\
\text { Standards } \\
\text { Cost } \\
\text { Accuracy } \\
\text { Sustainability }\end{array}$ & $\begin{array}{c}{[46,93]} \\
{[46,93]} \\
{[46,93]} \\
{[94,95]} \\
{[96-98]} \\
{[99-101]} \\
{[51,102,103]}\end{array}$ \\
\hline
\end{tabular}




\subsection{Input Determinants Impact Innovation-Decision Output}

3.1.1. Seller

The first stage of industrial buyer innovation adoption starts from problem identification and need recognition in the marketplace [73,76,77,104-108], where sellers and buyers exchange information and interact through different communication channels and influencers (stimuli) [42-44,46,70-72]. The organizational goal is a prioritized input to tackle problems that existing solutions cannot solve [41,43,47,73-75]. Accordingly, we posit that the first stage will lead buyers to assess the new SEAD technology, which they will explore, evaluate and adopt as a solution for their needs:

Hypothesis $\mathbf{1}$ (H1). The greater the marketplace stimulus interactions among sellers and buyers, the greater the seller's effective influence on new technology adoption.

\subsubsection{Buyer}

Consumer behavior theories and technology acceptance models are parallel with Rothwell's Coupling Model of Innovation Process [48], in which information exchange, communication, and feedback are vital to innovation success in the marketplace. Integration and balance between technological development (technology-push) and market forces (demand-pull) are strategized in efficiently optimizing new inventions for internal and external organizations through idea generation, $\mathrm{R} \& \mathrm{D}$, production and marketing [78]. The new co-created product is customized according to the user's input, strengthening both business relationships and appreciation of innovation [79]. The unsolved problem will be clearly defined when sellers and buyers build a network of trusting relationships with commitment and foster a shared appreciation of innovation development $[44,80,81,83]$. Thus:

Hypothesis 2 (H2). The greater the buyer interactions with sellers in problem identification, the greater the buyer's effective influence on new technology adoption.

\subsection{Process Determinants Impact Innovation-Decision Output}

The second stage of IBIA involves the technology acceptance processes, which are influenced by four determinants: environment, internal organization, internal people characteristics, and invented technology advantage.

\subsubsection{Environment}

To explore the solution to a problem, macro-environmental factors, which are regulations, economics, society and culture, technological infrastructure, and natural environment, have to be scrutinized [42-44]. Regulations deter incremental innovations yet encourage breakthroughs in a growing market [85]. The positive long-term regulatory implications are more justifiable on technological success or failure as they pressure companies to innovate [84]. Consumer choices in the market are influenced by economic, sociocultural, and environmental conditions $[87,89]$, and in terms of environment, respondents were asked to rate how much regulations, economics, society and culture, technological infrastructure and impact on the natural environment had on their buying decision. Taken together, we hypothesize that:

Hypothesis 3 (H3). The environment has a positive effect on the new technology adoption.

\subsubsection{Internal Organization}

A favorable internal organization environment increases technology adoption [60]. The organizational structure (e.g., managerial empowerment and organization size) has an effect on technology acceptance $[44,46,54,90,109]$, which is due to the firm's technology competency $[42,55]$ and risk tolerance [98]. If potential users can accept organizational-related risks, they will be willing to adopt the new technology. In short, organizational structure, technology competence and risk tolerance have influential effects on technology adoption. 
Hypothesis 4 (H4). The internal organization has a positive effect on the new technology adoption.

\subsubsection{Internal People Characteristics}

To decide whether to adopt or reject an innovation, the organization requires internal technological cognoscenti and individual employees to partake in finding and assessing pertinent solutions. Perceived usefulness, perceived ease of use [49], and internal people characteristics [52] impact user's attitudes, intentions and behaviors [50,51]. Discomfort and insecurity stop both novices and technological talents from adopting new technologies [91]. Perceived usefulness, perceived ease of use and characteristics of internal people have influential effects on technology adoption. Therefore:

Hypothesis 5 (H5). The internal people characteristics have a positive effect on the new technology adoption.

\subsubsection{Invented Technology Advantage}

The perceived characteristics of innovation (i.e., relative advantage, complexity, and compatibility) lead to adoption in the innovation-decision process $[46,93]$. Perceived superior technological advantages with less spent resources will make users more likely to adopt new technology [99-101]. Additional attributes (i.e., standards, cost, accuracy, sustainability) of SEAD technology are taken to benchmark against existing rivals by industrial users. If users perceive that SEAD is advantageous, they will be more likely to adopt it. Hence:

Hypothesis 6 (H6). If the new technology is expected to have a positive effect on the internal organization, this will increase the buyer's likelihood of adopting it.

\subsection{Output}

The last stage of the IBIA process is the innovation-decision (a binary dependent variable): adoption or rejection of SEAD technology. IBIA framework combines collected data and explored solutions from communications among influencing groups of people in an industry that leads to technology acceptance or rejection.

\section{Research Methodology}

\subsection{Construct Measures}

SEAD is an emerging technology of recent decades that allows any user to quantify toxic heavy metal ions and other chemicals, which previously could only be analyzed by expert technicians in state-of-the-art laboratories. The objective of this research is to study the factors impacting SEAD technology adoption in the manufacturing industry. A questionnaire was designed to scrutinize adoption determinants of the IBIA model. A fivepoint Likert scale ranging from 1 (strongly disagree) to 5 (strongly agree) was used for all measurement items. The dichotomous dependent variable (yes/no) was utilized to assess the adoption intention, as in whether a given company is interested in purchasing SEAD or not. Table 1 summarizes the principal construct measures. The six independent variables were selected to develop a binary logistic regression model from an extensive literature review based on a combination of existing industrial consumer behavior and technology acceptance theories over the past 50 years. Principal-components factor analysis was used to evaluate the construct validity of all measurement items. A good match between the data and the research model was assessed by the Hosmer-Lemeshow test and likelihood-ratio test. As this study focuses on identifying factors that can predict adopters and non-adopters of SEAD technology, the relationships among six factors were not in our research scope.

\subsection{Data Collection and Sample}

Data were collected by telephone questionnaire consisting of three sections: screening questions, market potential of SEAD for heavy metal detection, and SEAD technology 
acceptance predictors. From the population of 6139 Group 3 classified factories in Thailand that are legally mandated by Factory Act B.E. 2535 to monitor heavy metal contamination in sewage sludge, we randomly approached 3608 qualified firms. The response rate was $11.1 \%$. We received 400 valid responses, which is statistically sufficient (at least $n=362$ ) according to Cochran's sample size formula [110].

\subsection{Instrument Validation}

Questionnaires were reviewed by academic experts and professional practitioners to ensure content validity before launching the telephone survey. Cronbach's alpha coefficient confirmed internal consistency and construct reliability. As presented in Table 2, all Cronbach's alpha coefficients are higher than 0.7 , certifying the reliability of the questionnaire used in this study.

Table 2. $\alpha$ coefficients and factor analysis.

\begin{tabular}{|c|c|c|c|c|c|c|}
\hline & SE & BU & EN & IO & IP & IT \\
\hline$\alpha$ coefficient & 0.77 & 0.89 & 0.84 & 0.85 & 0.90 & 0.94 \\
\hline SE1 & 0.78 & & & & & \\
\hline SE2 & 0.80 & & & & & \\
\hline SE3 & 0.59 & & & & & \\
\hline BU1 & & 0.77 & & & & \\
\hline BU2 & & 0.76 & & & & \\
\hline BU3 & & 0.70 & & & & \\
\hline EN1 & & & 0.79 & & & \\
\hline EN2 & & & 0.54 & & & \\
\hline EN3 & & & 0.62 & & & \\
\hline EN4 & & & 0.61 & & & \\
\hline EN5 & & & 0.63 & & & \\
\hline IO1 & & & & 0.70 & & \\
\hline $\mathrm{IO} 2$ & & & & 0.74 & & \\
\hline $\mathrm{IO} 3$ & & & & 0.62 & & \\
\hline IP1 & & & & & 0.59 & \\
\hline IP2 & & & & & 0.63 & \\
\hline IP3 & & & & & 0.66 & \\
\hline IT1 & & & & & & 0.72 \\
\hline IT2 & & & & & & 0.79 \\
\hline IT3 & & & & & & 0.76 \\
\hline IT4 & & & & & & 0.80 \\
\hline IT5 & & & & & & 0.77 \\
\hline IT6 & & & & & & 0.79 \\
\hline IT7 & & & & & & 0.75 \\
\hline
\end{tabular}

SE: seller; BU: buyer; EN: environment; IO: internal organization; IP: internal people characteristics; IT: invented technology advantage.

Factor analysis was used to examine the variability of the measured constructs. Data from 400 factories were analyzed using principal-component factor analysis (PCA). PCA and binary logistic regression are both suitable for making predictive models. Their main goal is to eliminate redundant and correlated variables in a data matrix since they directly impact model performances. Moreover, PCA can identify patterns, capture variations in data and facilitate a predictive model with accurate results [111,112]. Items and their constructs were established as having a good fit by a varimax orthogonal rotation, for which the factor loading should be more than 0.3-0.4 [113]. The Kaiser-Meyer-Olkin (KMO) test value is 0.995 , ensuring that the obtained data are adequate and suitable for factor analysis [114]. Variables are independent, as Bartlett's test of sphericity confirms, with a significant $p$-value of $<0.05$ [115]. As seen in Table 2, each factor and measurement item are harmonized. 


\section{Data Analysis and Findings}

Analysis of data collected from 400 corporations in Thailand revealed that sellers, buyers, internal organization and invented technology advantage variables predicted industrial innovation adoption based on binary logistic regression. Our proposed model's overall forecasting precision was $78 \%$, affirming its greater predictive accuracy over a random assumption.

\section{Responding Organization Demographics}

Among the 400 responding organizations, $223(55.8 \%)$ adopted SEAD technology, and $177(44.25 \%)$ did not. Despite the low response rate (11.1\%), the Pearson Chi-Square test $(p=0.37)$ indicates that there was no non-response bias. As shown in Table 3, the majority of companies had been established for longer than 10 years, with more than 16,000,000 USD annual sales revenue. We managed to approach decision-makers and influencers, who were directly involved in toxic heavy metal monitoring in factories.

Table 3. Samples Demographic.

\begin{tabular}{ccc}
\hline Category & Frequency & Percentage \\
\hline Company age (years) & & \\
\hline$<10$ & 69 & 17.25 \\
$11-30$ & 208 & 52.00 \\
$31-50$ & 95 & 23.75 \\
$>50$ & 28 & 7.00 \\
\hline Registered capital (USD) & & \\
\hline$<50,000$ & 33 & 8.25 \\
$50,001-3,000,000$ & 204 & 51.00 \\
$>3,000,000$ & 163 & 40.75 \\
\hline Annual sales revenue (USD) & & \\
\hline$<600,000$ & 45 & 11.25 \\
600,001-3,000,000 & 80 & 20.00 \\
3,000,001-16,000,000 & 124 & 31.00 \\
$>16,000,000$ & 151 & 37.75 \\
\hline Respondent job roles & & \\
\hline Top management & 91 & 22.75 \\
Technical specialist & 67 & 16.75 \\
Procurement specialist & 31 & 7.75 \\
Quality specialist & 64 & 36.00 \\
Safety specialist & 147 &
\end{tabular}

Binary logistic regression assumptions require a theoretically developed model with the best set of independent variables and suitable data. The assessment is performed by evaluating the multicollinearity and goodness of fit indicators [116]. The logistic regression technique was used to examine our research model. The means of the six variables (composite scores) were calculated from 24 measurement item scores as shown in Table 4. In Model 1, all six variables were entered in one step. In order to conceptualize the model that best explains the technology adoption, the backward elimination regression was used as a model fitting technique to reduce non-significant predictor variables in Model 2.

Table 4. Means of the six independent innovation adoption predictors.

\begin{tabular}{ccccccc}
\hline & SE & BU & EN & IO & IP & IT \\
\hline All & 3.61 & 3.76 & 3.93 & 3.72 & 3.86 & 4.10 \\
Adopter & 3.95 & 4.07 & 4.15 & 4.04 & 4.15 & 4.36 \\
Non-Adopter & 3.19 & 3.36 & 3.65 & 3.32 & 3.49 & 3.77 \\
\hline
\end{tabular}


To avoid interrelations among the predictors, Hair et al. [113] suggested that the variance inflation factor (VIF) should be lower than 10, and the variables should have variance proportions below 0.9 in cases where condition indices are above 30. As shown in Table 5, all factors in this study have no multicollinearity.

Table 5. Multicollinearity Diagnostics.

\begin{tabular}{cccccccccc}
\hline \multirow{2}{*}{ Model } & VIF & $\begin{array}{c}\text { Condition } \\
\text { Index }\end{array}$ & \multicolumn{7}{c}{ Variance Proportions } \\
\cline { 4 - 10 } & & & Constant & SE & BU & EN & IO & IP & IT \\
\hline Constant & & 1.00 & 0.00 & 0.00 & 0.00 & 0.00 & 0.00 & 0.00 & 0.00 \\
SE & 2.46 & 16.19 & 0.20 & 0.30 & 0.06 & 0.01 & 0.00 & 0.01 & 0.04 \\
BU & 2.99 & 19.20 & 0.61 & 0.09 & 0.00 & 0.00 & 0.05 & 0.11 & 0.04 \\
EN & 2.94 & 24.75 & 0.05 & 0.03 & 0.33 & 0.01 & 0.47 & 0.01 & 0.15 \\
IO & 2.97 & 27.44 & 0.00 & 0.50 & 0.40 & 0.06 & 0.14 & 0.04 & 0.26 \\
IP & 3.42 & 32.25 & 0.13 & 0.03 & 0.15 & 0.49 & 0.03 & 0.57 & 0.08 \\
IT & 2.61 & 32.72 & 0.01 & 0.05 & 0.06 & 0.43 & 0.30 & 0.27 & 0.43 \\
\hline
\end{tabular}

Table 6 illustrates the predictive power and the goodness of fit of the research model. The research model's -2 Log likelihood value is less than the null model, indicating that the data and the model were compatible. However, Model 1 does not exhibit a good fit since its chi-square significance ( $p$-value) is less than 0.05 from the Hosmer-Lemeshow test. Model 2 indicates a good fit with Pseudo Cox \& Snell $R^{2}(0.30)$ and Nagelkerke $R^{2}(0.40)$. Therefore, the variables are considered to be significant predictors in Model 2 equation, which adequately describes the data.

Table 6. Predictive power and goodness of fit of the IBIA model.

\begin{tabular}{ccc}
\hline Statistical Tests & Model 1 & Model 2 \\
\hline -2 Log likelihood (Null Model) & 549.22 & 549.22 \\
-2 Log likelihood (Research Model) & 402.49 & 405.45 \\
Change in -2 Log likelihood & 146.73 & 143.77 \\
Hosmer and Lemeshow Chi-square & $9.77^{*}$ & $12.43^{* *}$ \\
Cox \& Snell R & 0.31 & 0.30 \\
Nagelkerke $\mathrm{R}^{2}$ & 0.41 & 0.40 \\
\hline
\end{tabular}

*p<0.05, ${ }^{* *} p>0.05$.

Table 7 indicates the predictive model's accuracy of classification between adopters and non-adopters between 2 models. Model 2 correctly predicted $84.3 \%$ of adopters and $70.1 \%$ of non-adopters. Model 2's overall forecasting precision was $78 \%$, affirming its greater predictive accuracy over a random assumption.

The Wald statistic was used to test the six hypothesized predictors. As reported in Table 8, seller, buyer, internal organization, and invented technology advantage determinants were significant at the $0.001,0.05$ and 0.10 thresholds, but environment, and internal people were non-significant discriminators. The $\beta$ coefficient signs characterize independent variable impacts on SEAD adoption. Therefore, seller, buyer, internal organization, and invented technology advantage factors positively influence new technology adoption. 
Table 7. Classification.

\begin{tabular}{|c|c|c|c|c|c|c|}
\hline \multirow{4}{*}{ Observed } & \multicolumn{6}{|c|}{ Predicted } \\
\hline & \multicolumn{3}{|c|}{ Model 1} & \multicolumn{3}{|c|}{ Model 2} \\
\hline & \multicolumn{2}{|c|}{ Logistic } & \multirow{2}{*}{$\%$ Correct } & \multicolumn{2}{|c|}{ Logistic } & \multirow{2}{*}{$\%$ Correct } \\
\hline & Adopter & Non-Adopter & & Adopter & Non-Adopter & \\
\hline Adopter & $187(83.9 \%)$ & $36(16.1 \%)$ & 83.9 & $188(84.3 \%)$ & $35(15.7 \%)$ & 84.3 \\
\hline Non-Adopter & $51(28.8 \%)$ & $126(71.2 \%)$ & 71.2 & $53(29.9 \%)$ & $124(70.1 \%)$ & 70.1 \\
\hline Overall & & & 78.3 & & & 78.0 \\
\hline
\end{tabular}

Table 8. Results of logistic regression analysis.

\begin{tabular}{ccccc}
\hline & \multicolumn{2}{c}{ Model 1 } & \multicolumn{2}{c}{ Model 2 } \\
\cline { 2 - 5 } Predictors & $\beta$ Coefficient & $\begin{array}{c}\text { Wald } \\
\text { Statistics }\end{array}$ & $\beta$ Coefficient & $\begin{array}{c}\text { Wald } \\
\text { Statistics }\end{array}$ \\
\hline Constant & $-8.37^{* * *}$ & 77.39 & $-8.61^{* * *}$ & 86.52 \\
Seller & $0.63^{*}$ & 6.22 & $0.65^{*}$ & 6.71 \\
Buyer & $0.54^{* *}$ & 3.09 & $0.44^{* *}$ & 2.46 \\
Environment & -0.49 & 1.93 & - & - \\
$\quad$ Internal & $0.87^{*}$ & 8.14 & $0.87^{* * *}$ & -11.14 \\
organization & 0.39 & 1.58 & - & - \\
Internal people & & & $0.41^{* *}$ & 3.16 \\
Invented & 0.38 & 1.90 & & \\
technology & & &
\end{tabular}

\section{Discussions}

This study aims to adapt the IBIA framework to explain SEAD adoption. Empirical results demonstrated significant variables as predictive factors of the IBIA framework. Each SEAD adoption determinant is discussed as follows:

\subsection{Seller Context}

The seller context had significant positive effects on SEAD adoption in terms of information exchange, organizational goals, and problem-solving abilities. SEAD technology for toxic heavy metal detection is new to consumers, therefore communication to stimulate awareness should focus on understanding and establishing mutual goals between sellers and buyers. Since all customers may not embrace a new technology, information exchange is a key to resolving conflict, especially in B2B markets as sellers and buyers have closer relationships than B2C markets [117]. To exemplify this, instead of satisfying self-interests, the industry targeted mutual goals in preventing and fraudulent products to enter the pharmaceutical supply chain. With shared information from sellers through RFID adoption, the industry interactively solved counterfeit problems. Sellers and buyers benefited from improving the visibility, security and traceability of their products [118]. In short, our research finding is consistent with past studies $[41,46-48,93]$, suggesting that technology adoption is a consequence of seller interactions.

\subsection{Buyer Context}

The buyer context had significant positive effects on SEAD adoption in innovation coupling, co-creation, and networking and commitment perspectives. The feedback linking various in-house functions for both intra-organization and extra-organization is critical in the innovation coupling model [48]. The research on nanotechnology-based and processbased innovations affirmed that the end product features were outputs from coupling strategies [119]. The increasing value co-created between buyers and manufacturers led 
to better productivity and efficiency by using information technology to eliminate wastes in Romanian companies [120]. Likewise, collaborative innovation R\&D projects have succeeded due to networking and commitment. The long-term strategic partnership with critical members is a foundation of commercializing high-technological innovation. Palm Pilot, a professional PDA device was highly successful due to early adopter networks of software and hardware manufacturers, which resulted in market growth [121]. The network effect helped RFID adoption in the healthcare industry [122]. Benefits and values of goods increase along with a rising number of users. Therefore, the buyers have positive effects on new technology adoption.

\subsection{Environment Context}

Paradoxically, the environment context determinants had non-significant negative effects on SEAD adoption. The environmental context also had a negative impact on technology adoption in small businesses [123]. Larger and older firms were less innovative from environmental dynamics that they were surrounded [124]. In contrast, this finding is inconsistent with the RFID adoption in Taiwanese manufacturing companies based on the adapted TOE framework. Wang et al. [34] found that competitive pressure and trading partner pressure had positive influences, but information intensity had a negative impact on RFID adoption. The three environmental contexts of the adapted TOE framework may not be compatible with five macro-environmental factors (regulations, economics, society and culture, technological infrastructure, and natural environment) included in the IBIA framework. However, the environmental context also had a negative impact on small enterprises [123]. Consequently, future research needs to consider other factors (e.g., firm revenue and age) to adapt the framework for better generalizability.

\subsection{Internal Organization Context}

As hypothesized, the internal organization context was a significantly positive discriminator in aspects of organizational structure, technology competence, and risks. This finding is consistent with previous studies on the adoption of similar technology. Technical problems associated with implementing RFID technology should be considered managerial and organizational issues [125]. To be more specific, lack of organizational support [126,127], trust issues [128], uncertain return on investment [129], and technological threats [130] are barriers to RFID adoption in healthcare and wireless environmental monitoring systems. Therefore, if SEAD technology provides complementary assets to organization and industry levels, users will be willing to adopt it as the total economic value added surpasses organizational trade-offs.

\subsection{Internal People Context}

The characteristics of internal people context determinants had insignificant positive effects on SEAD adoption. Han et al. [131] suggested that employee participation in decision-making processes contributed to personal and firm innovativeness in hightechnology organizations. Employees tended to make decisions after they perceived a minimized risk supported by data and technologies in software firms [132]. The results coincide with NFC, RFID, and self-service technologies adoption research [133-135]. In contrast, technology acceptance was negatively affected by perceived usefulness and perceived ease of use in dimensions of perceived security, perceived risks, and privacy concerns. Additionally, it is difficult to convince people due to their commitment to team members and traditions. From the national perspective, Thai culture leans slightly towards uncertainty avoidance, but is highly collectivistic and conservative [136]. As a result, internal people characteristics hinder technology adoption when users have negative attitudes and experiences $[60,137-139]$. 


\subsection{Invented Technology Advantage}

SEAD's technological features were found to have a significantly positive influence on its adoption. The average perceived invented technology advantage levels of adopters (4.36) and non-adopters (3.77) were the highest among other predictors as shown in Table 4. The characteristics and applications of the SEAD sensors were also important for prospective technological adopters. Wireless chemical sensors technologies were successfully applied in four major applications: environmental monitoring, healthcare, sport and physiology, and food and agriculture [21]. The well-known technologies similar to SEAD in the market are blood glucose monitoring and physiological signal tracking systems. From Rogers' DOI model [46], it is clear that SEAD achieved relative advantage, compatibility and complexity criteria. However, the technology needs to be more accessible. Potential users were unsure about replacing conventional technologies with SEAD due to limitations in trialability and observability. Our demonstrated SEAD system prototype comprised of four components, which are (1) nanomaterials modified screen-printed graphene electrodes (SPGEs) or sensors, (2) supporting electrolytes, (3) a wireless potentiostat, and (4) a smartphone. The majority of the respondents and adopting prospects from our samples were eager to try and compare SEAD with their current technologies. Similarly, non-adopting respondents were reluctant to adopt SEAD because they had no experience from product demonstrations and certified test results.

To discuss the findings with the literature, the accuracy and reliability of SEAD are comparable to conventional bulky electrochemical workstations [28-30]. Additionally, SEAD is integrated with smartphone communication technologies. For instance, NFC mobile technology is widely adopted due to its compatibility, cost-effectiveness and less complex characteristics in banking and IT sectors [98]. The fewer resources utilized, the more likely the innovation will be adopted [93] as users spent less time and emotional efforts on a new technology [99]. However, the industrial standard is also a crucial factor that influences buyer's decisions. Before a new technology standard is fully established, the market will remain competing in product innovations that will replace old technologies $[140,141]$. Regardless of adoption intention, important technological attributes are accuracy, standardization, sustainability, convenience, compatibility, minimized costs and less complexity. Therefore, SEAD technological advantages have a positive effect on its adoption.

Empirical results show six predictive determinants and 24 sub-contexts effectively conceptualize our research model. The final result yielded $78 \%$ forecasting accuracy from the Industrial Buyers Innovation Adoption (IBIA) model. This research opens up undiscovered academic and management terrains. The framework is an alternative handson navigator for understanding, creating and analyzing B2B innovations that reflect all fundamental foundations of sustainability, which are society (people), the environment (planet), and the economy (profit).

\section{Conclusions}

Foremostly, SEAD technology offers an alternative approach for heavy metal quantification. The synergy of smartphone and electrochemical sensor technologies has been developed in laboratories and has revolutionized manufacturing industries due to its speed, reproducibility, and reliable analytical capability [13,142]. Although SEAD can deliver competitive advantages to organizations, its adoptability is still limited in a particular niche market among innovators in laboratories. Thus, understanding the magnitude of innovation adoption predictors is crucially important.

Furthermore, this study formulates IBIA model, an ambitious framework based on the integration of B2B consumer behavior theories and technology adoption models. IBIA framework is empirically proven to forecast the adoption rate for SEAD technology for heavy metal detection depending on six determinants: seller, buyer, environment, internal organization, internal people characteristics, and invented technology advantage. Our results have an implication that firm-level determinants are essential for industrial tech- 
nology adoption. The seller, the buyer, the internal organization and invented technology advantages were found to be significant adoption discriminators. Surprisingly, the external environment and internal people characteristics were the barriers to innovation adoption. Data uncertainty and variations in effects are acceptable in research. Thus, statistical inference should always be skeptical and recognize underlying problems with thoughtfulness, openness, and modesty [143].

Finally, this study has limitations that offer opportunities for future research. Future research on relationships among independent variables may be useful for understanding their causality as binary logistic regression focuses mainly on distinguishing adopters and non-adopters from the single relationship between the independent and dependent variables [113]. Additionally, results may not be widely generalizable, since the sample is only of industrial manufacturers in Thailand, who are required by law to adhere to conventional technologies. Besides that, future research may apply IBIA to other new technologies to apply, validate and evaluate this predictive model. Once the IBIA model is rigorously revised and validated from data obtained from various new technologies, it could become an alternative managerial tool for holistically assessing and creating adoptable innovative business models beyond B2B marketplaces. The ultimate goal of SEAD is not about saving money or time, but it is about saving lives in global communities as well as supporting four UN sustainable development goals (UN SDG), which are (1) clean water and sanitation, (2) industry, innovation and infrastructure, (3) life on land and (4) life below water.

Author Contributions: Conceptualization, W.T.; methodology, W.T.; validation, W.T.; formal analysis, W.T.; investigation, W.T.; writing—original draft preparation, W.T.; writing—review and editing, A.C. and O.C.; visualization, W.T.; supervision, O.C., A.C. and S.C. All authors have read and agreed to the published version of the manuscript.

Funding: This research received no external funding.

Institutional Review Board Statement: Ethical review and approval was not required for this study on human participants in accordance with the local legislation and institutional requirements.

Informed Consent Statement: All subjects gave their informed consent for inclusion before they participated in the study.

Data Availability Statement: Not applicable.

Acknowledgments: This research was supported by the 90th Anniversary of Chulalongkorn University Fund (Ratchadaphiseksomphot Endowment Fund), the Ministry of Higher Education, Science, Research and Innovation, the National Research Council of Thailand (NRCT Grant No. N41A640073) as well as Technopreneurship and Innovation Management Program, Graduate School, Chulalongkorn University, Thailand. The authors would like to thank Research Clinic Unit, The Office of Research Affairs, Chulalongkorn University for proof-editing this manuscript.

Conflicts of Interest: The authors declare no conflict of interest.

Appendix A

Table A1. Measurement items of the independent variables. 
Table A1. Cont.

\section{Independent Variables}

Buyer (BU)

Environment (EN)

Internal organization (IO)

Internal people characteristics (IP)

\section{Measurement Items}

BU1. The innovation coupling model helps the buyer to assess and consider using the new heavy metal testing technology as buyers and sellers both sharing feedbacks in the marketplace.

BU2. Product co-creation and co-development help the buyer to consider using the new heavy metal testing technology as buyers and sellers both sharing resources in the marketplace.

BU3. Networking and commitment between organizations are important for buyers to assess and consider using the new heavy metal testing device.

EN1. Customer requirements, industrial standards, regulations and laws influence the adoption of the new heavy metal testing technology in your organization.

EN2. Economic situations influence the adoption of the new heavy metal testing technology in your organization.

EN3. Society, stakeholders and cultures influence the adoption of the new heavy metal testing technology in your organization.

EN4. The technology infrastructures (e.g., communication technologies embedded in testing instruments, smartphone communication technologies) influence the adoption of the new heavy metal testing technology in your organization.

EN5. Impacts on the natural environment influence the adoption of the new heavy metal testing technology in your organization. (For example, the new technology helps you to prevent and monitor heavy metal leakages into the environment or the devices are made of biodegradable parts.)

IO1. Organizational structure influences the adoption of the new heavy metal testing technology in your organization. (Organizational structure includes organization size, resources, power centralization, communication, etc.) IO2. Technology competency and compatibility influence the adoption of the new heavy metal testing technology in your organization.

(For example, available communication technologies among testing instruments in the organization support the new technology. The new heavy metal test kit would require only wireless communication technology between a smartphone and a test kit.)

IO3. Your organization can accept changes and risks from the new heavy metal testing technology that would help your organization to solve problems and become more competitive.

IP1. Perceived usefulness of the new heavy metal testing technology will help you to work more efficiently, which will result in an influence on the adoption of the new heavy metal testing technology in your organization.

IP2. Perceived ease of use of the new heavy metal testing technology will help you to work more efficiently, which will result in an influence on the adoption of the new heavy metal testing technology in your organization.

IP3. Experiences, knowledge, abilities and characteristics of internal people influence the adoption of the new heavy metal testing technology in your organization.

IT1. If the new heavy metal testing technology is more advantageous than the current technology that you are using in terms of uses (e.g., portability, fast analysis, no expert skills and knowledge required), your organization is more likely to adopt this new technology.

IT2. If the new heavy metal testing technology is more advantageous than the current technology that you are using in terms of standards, your organization is more likely to adopt this new technology.

IT3. If the new heavy metal testing technology is more advantageous than the current technology that you are using in terms of costs, your organization is more likely to adopt this new technology.

IT4. If the new heavy metal testing technology is more advantageous than the current technology that you are using in terms of accuracy, your organization is more likely to adopt this new technology.

IT5. If the new heavy metal testing technology is more advantageous than the current technology that you are using in terms of complexity, your organization is more likely to adopt this new technology.

IT6. If the new heavy metal testing technology is more advantageous than the current technology that you are using in terms of compatibility, your organization is more likely to adopt this new technology.

IT7. If the new heavy metal testing technology is more advantageous than the current technology that you are using in terms of sustainability, your organization is more likely to adopt this new technology. 


\section{References}

1. Attina, T.M.; Trasande, L. Economic costs of childhood lead exposure in low-and middle-income countries. Environ. Health Perspect. 2013, 121, 1097-1102. [CrossRef]

2. Bureau of Epidemiology. Available online: http://www.boe.moph.go.th/Annual/AESR2015/aesr2558/Part\%201/09 /heavymetal.pdf (accessed on 8 August 2020).

3. World Health Organization. Childhood Lead Poisoning; WHO Press: Geneva, Switzerland, 2010.

4. ResearchAndMarkets. Global Heavy Metal Testing Market Report 2021: Trends, Forecast, and Competitive Analysis 2013-2024 by Product Arsenic, Cadmium, Lead, Mercury \& Technology ICP-MS \& -OES, AAS; 1945-8711, NewsRX LLC; ResearchAndMarkets: Dublin, Irleand, 2021; p. 1751. Available online: https:/ / www.researchandmarkets.com/reports/5003533/heavy-metal-testing-marketreport-trends?utm_source=BW\&utm_medium=PressRelease\&utm_code=f63tdc\&utm_campaign=1525768+-+Global+Heavy+ Metal+Testing+Market+Report+2021\%3a+Trends $\% 2 c+$ Forecast $\% 2 c+$ and +Competitive+Analysis+2013-2024+by+Product+ (Arsenic\%2c+Cadmium\%2c+Lead\%2c+Mercury)+\%26+Technology+(ICP-MS+\%26+-OES\%2c+AAS)\&utm_exec=chdo54prd (accessed on 3 May 2021).

5. Magee, L.; Scerri, A.; James, P.; Thom, J.A.; Padgham, L.; Hickmott, S.; Deng, H.; Cahill, F. Reframing social sustainability reporting: Towards an engaged approach. Environ. Dev. Sustain. 2013, 15, 225-243. [CrossRef]

6. Schumpeter, J.A. The Theory of Economic Development: An Inquiry into Profits, CapitaI, Credit, Interest, and the Business Cycle; Routledge: New York, NY, USA, 2017.

7. OECD Observer. Science, Technology and Innovation in the New Economy; OECD: Paris, France, 2000.

8. Chemicals Strategy for Sustainability towards a Toxic-Free Environment. Available online: https://ec.europa.eu/environment/ pdf/chemicals/2020/10/Strategy.pdf (accessed on 1 July 2021).

9. Oldham, K.B. Trends in electrochemical instrumentation and modeling. J. Solid State Electrochem. 2011, 15, 1697-1698. [CrossRef]

10. Brooks, J.C.; Mace, C.R. Scalable Methods for Device Patterning as an Outstanding Challenge in Translating Paper-Based Microfluidics from the Academic Benchtop to the Point-of-Care. J. Anal. Test. 2019, 3, 50-60. [CrossRef]

11. Hoekstra, R.; Blondeau, P.; Andrade, F.J. Distributed electrochemical sensors: Recent advances and barriers to market adoption. Anal. Bioanal. Chem. 2018, 410, 4077-4089. [CrossRef]

12. Akyazi, T.; Basabe-Desmonts, L.; Benito-Lopez, F. Review on microfluidic paper-based analytical devices towards commercialisation. Anal. Chim. Acta 2018, 1001, 1-17. [CrossRef]

13. Ataide, V.N.; Mendes, L.F.; Gama, L.I.; de Araujo, W.R.; Paixao, T.R. Electrochemical paper-based analytical devices: Ten years of development. Anal. Methods 2020, 12, 1030-1054. [CrossRef]

14. Mankins, J.C. Technology Readiness Levels: A White Paper; NASA, Office of Space: Washington, DC, USA, 1995.

15. Li, F.; Hu, Y.; Li, Z.; Liu, J.; Guo, L.; He, J. Three-dimensional microfluidic paper-based device for multiplexed colorimetric detection of six metal ions combined with use of a smartphone. Anal. Bioanal. Chem. 2019, 411, 6497-6508. [CrossRef]

16. Xiao, W.; Xiao, M.; Fu, Q.; Yu, S.; Shen, H.; Bian, H.; Tang, Y. A portable smart-phone readout device for the detection of mercury contamination based on an aptamer-assay nanosensor. Sensors 2016, 16, 1871. [CrossRef]

17. Sajed, S.; Kolahdouz, M.; Sadeghi, M.A.; Razavi, S.F. High-Performance Estimation of Lead Ion Concentration Using SmartphoneBased Colorimetric Analysis and a Machine Learning Approach. ACS Omega 2020, 5, 27675-27684. [CrossRef]

18. Aragay, G.; Pons, J.; Merkoçi, A. Recent trends in macro-, micro-, and nanomaterial-based tools and strategies for heavy-metal detection. Chem. Rev. 2011, 111,3433-3458. [CrossRef]

19. Arduini, F.; Palleschi, G. Screening and confirmatory methods for the detection of heavy metals in foods. In Persistent Organic Pollutants and Toxic Metals in Foods; Elsevier: Amsterdam, The Netherlands, 2013; pp. 81-109.

20. Simões, F.R.; Xavier, M.G. Electrochemical sensors. Nanosci. Its Appl. 2017, 74, 155-178.

21. Kassal, P.; Steinberg, M.D.; Steinberg, I.M. Wireless chemical sensors and biosensors: A review. Sens. Actuators B Chem. 2018, 266, 228-245. [CrossRef]

22. Skoog, D.; Holler, F.; Crouch, S. Principles of Instrumental Analysis; Cengage Learn: Boston, MA, USA, 2017.

23. Chaiyo, S.; Apiluk, A.; Siangproh, W.; Chailapakul, O. High sensitivity and specificity simultaneous determination of lead, cadmium and copper using $\mu \mathrm{PAD}$ with dual electrochemical and colorimetric detection. Sens. Actuators B Chem. 2016, 233, 540-549. [CrossRef]

24. Pungjunun, K.; Chaiyo, S.; Jantrahong, I.; Nantaphol, S.; Siangproh, W.; Chailapakul, O. Anodic stripping voltammetric determination of total arsenic using a gold nanoparticle-modified boron-doped diamond electrode on a paper-based device. Microchim. Acta 2018, 185, 1-8. [CrossRef]

25. Pungjunun, K.; Nantaphol, S.; Praphairaksit, N.; Siangproh, W.; Chaiyo, S.; Chailapakul, O. Enhanced sensitivity and separation for simultaneous determination of tin and lead using paper-based sensors combined with a portable potentiostat. Sens. Actuators B Chem. 2020, 318, 128241. [CrossRef]

26. Bard, A.J.; Faulkner, L.R. Fundamentals and applications: Electrochemical methods. Electrochem. Methods $2001,2,482$.

27. Rowe, A.A.; Bonham, A.J.; White, R.J.; Zimmer, M.P.; Yadgar, R.J.; Hobza, T.M.; Honea, J.W.; Ben-Yaacov, I.; Plaxco, K.W. CheapStat: An open-source, “Do-It-Yourself” potentiostat for analytical and educational applications. PLoS ONE 2011, 6, e23783. [CrossRef]

28. Steinberg, M.D.; Kassal, P.; Kereković, I.; Steinberg, I.M. A wireless potentiostat for mobile chemical sensing and biosensing. Talanta 2015, 143, 178-183. [CrossRef] 
29. Krorakai, K.; Klangphukhiew, S.; Kulchat, S.; Patramanon, R. Smartphone-Based NFC Potentiostat for Wireless Electrochemical Sensing. Appl. Sci. 2021, 11, 392. [CrossRef]

30. Mukherjee, S.; Bhattacharyya, S.; Ghosh, K.; Pal, S.; Halder, A.; Naseri, M.; Mohammadniaei, M.; Sarkar, S.; Ghosh, A.; Sun, Y. Sensory development for heavy metal detection: A review on translation from conventional analysis to field-portable sensor. Trends Food Sci. Technol. 2021, 109, 674-689. [CrossRef]

31. Khorov, E.; Kiryanov, A.; Lyakhov, A.; Bianchi, G. A tutorial on IEEE 802.11 ax high efficiency WLANs. IEEE Commun. Surv. Tutor. 2018, 21, 197-216. [CrossRef]

32. Woolley, M.; Schmidt, S. Bluetooth 5 Go Faster. Go Further. Bluetooth ${ }^{\circledR}$ Core Specification Version 5.0 Feature Enhancements. 2018. Available online: https://www.bluetooth.com/wp-content/uploads/2019/03/Bluetooth_5-FINAL.pdf (accessed on 10 January 2021).

33. Sun, A.C.; Hall, D.A. Point-of-care smartphone-based electrochemical biosensing. Electroanalysis 2019, 31, 2-16. [CrossRef]

34. Wang, Y.-M.; Wang, Y.-S.; Yang, Y.-F. Understanding the determinants of RFID adoption in the manufacturing industry. Technol. Forecast. Soc. Chang. 2010, 77, 803-815. [CrossRef]

35. Quinn, A.D.; Dixon, D.; Meenan, B.J. Barriers to hospital-based clinical adoption of point-of-care testing (POCT): A systematic narrative review. Crit. Rev. Clin. Lab. Sci. 2016, 53, 1-12. [CrossRef] [PubMed]

36. Korte, B.J.; Rompalo, A.; Manabe, Y.C.; Gaydos, C.A. Overcoming challenges with the adoption of point-of-care testing: From technology push and clinical needs to value propositions. Point Care 2020, 19, 77-83. [CrossRef]

37. Kotler, P.; Turner, R.E. Marketing Management: Analysis, Planning, Implementation, and Control; Prentice Hall: Upper Saddle River, NJ, USA, 1997; Volume 9.

38. Jacoby, J. Consumer psychology as a social psychological sphere of action. Am. Psychol. 1975, 30, 977. [CrossRef]

39. Jacoby, J.; Morrin, M. Consumer psychology. In International Encyclopedia of the Social E Behavioral Sciences, 2nd ed.; Elsevier Inc.: Amsterdam, The Netherlands, 2015; pp. 738-743.

40. Lingqvist, O.; Plotkin, C.L.; Stanley, J. Do you really understand how your business customers buy. McKinsey Q. 2015,1 , 74-85.

41. The New B2B Buying Process. Available online: https://www.gartner.com/en/sales-service/insights/b2b-buying-journey (accessed on 8 August 2020).

42. Webster, F.E., Jr.; Wind, Y. A general model for understanding organizational buying behavior. J. Mark. 1972, 36, 12-19. [CrossRef]

43. Sheth, J.N. A model of industrial buyer behavior. J. Mark. 1973, 37, 50-56. [CrossRef]

44. Johnston, W.J.; Lewin, J.E. Organizational buying behavior: Toward an integrative framework. J. Bus. Res. 1996, 35, 1-15. [CrossRef]

45. Abratt, R. Industrial buying in high-tech markets. Ind. Mark. Manag. 1986, 15, 293-298. [CrossRef]

46. Rogers, E.M. Diffusion of Innovations; Simon and Schuster: New York, NY, USA, 2010.

47. Utterback, J.M. The process of technological innovation within the firm. Acad. Manag. J. 1971, 14, 75-88.

48. Rothwell, R. Towards the fifth-generation innovation process. Int. Mark. Rev. 1994. [CrossRef]

49. Davis, F.D.; Bagozzi, R.P.; Warshaw, P.R. User acceptance of computer technology: A comparison of two theoretical models. Manag. Sci. 1989, 35, 982-1003. [CrossRef]

50. Ajzen, I.; Fishbein, M. Attitude-behavior relations: A theoretical analysis and review of empirical research. Psychol. Bull. 1977, 84, 888-918. [CrossRef]

51. Ajzen, I. From intentions to actions: A theory of planned behavior. In Action Control; Springer: Berlin/Heidelberg, Germany, 1985; pp. 11-39.

52. Venkatesh, V.; Davis, F.D. A theoretical extension of the technology acceptance model: Four longitudinal field studies. Manag. Sci. 2000, 46, 186-204. [CrossRef]

53. Venkatesh, V.; Bala, H. Technology acceptance model 3 and a research agenda on interventions. Decis. Sci. 2008, 39, 273-315. [CrossRef]

54. Tornatzky, L.G.; Fleischer, M.; Chakrabarti, A.K. Processes of Technological Innovation; Lexington Books: Lexington, MA, USA, 1990.

55. Zhu, K.; Kraemer, K.L.; Xu, S. The process of innovation assimilation by firms in different countries: A technology diffusion perspective on e-business. Manag. Sci. 2006, 52, 1557-1576. [CrossRef]

56. McGowan, M.K.; Madey, G.R. Adoption and implementation of electronic data interchange. In Information Systems Innovation and Diffusion: Issues and Directions; Idea Group Publishing: London, UK, 1998; pp. 116-178.

57. Iacovou, C.L.; Benbasat, I.; Dexter, A.S. Electronic data interchange and small organizations: Adoption and impact of technology. MIS Q. 1995, 19, 465-485. [CrossRef]

58. Gibbs, J.L.; Kraemer, K.L. A cross-country investigation of the determinants of scope of e-commerce use: An institutional approach. Electron. Mark. 2004, 14, 124-137. [CrossRef]

59. Teo, H.-H.; Wei, K.K.; Benbasat, I. Predicting intention to adopt interorganizational linkages: An institutional perspective. MIS $Q$. 2003, 27, 19-49. [CrossRef]

60. Venkatesh, V.; Morris, M.G.; Davis, G.B.; Davis, F.D. User acceptance of information technology: Toward a unified view. MIS Q. 2003, 27, 425-478. [CrossRef]

61. Davis, F.D.; Bagozzi, R.P.; Warshaw, P.R. Extrinsic and intrinsic motivation to use computers in the workplace 1. J. Appl. Soc. Psychol. 1992, 22, 1111-1132. [CrossRef] 
62. Thompson, R.L.; Higgins, C.A.; Howell, J.M. Personal computing: Toward a conceptual model of utilization. MIS Q. 1991, 15, 125-143. [CrossRef]

63. Moore, G.C.; Benbasat, I. Development of an instrument to measure the perceptions of adopting an information technology innovation. Inf. Syst. Res. 1991, 2, 192-222. [CrossRef]

64. Taylor, S.; Todd, P. Assessing IT usage: The role of prior experience. MIS Q. 1995, 19, 561-570. [CrossRef]

65. Compeau, D.R.; Higgins, C.A. Computer self-efficacy: Development of a measure and initial test. MIS Q. 1995, 19, 189-211. [CrossRef]

66. Bagozzi, R.P. The legacy of the technology acceptance model and a proposal for a paradigm shift. J. Assoc. Inf. Syst. 2007, 8, 3. [CrossRef]

67. Van Raaij, E.M.; Schepers, J.J. The acceptance and use of a virtual learning environment in China. Comput. Educ. 2008, 50, 838-852. [CrossRef]

68. Li, J. Blockchain technology adoption: Examining the fundamental drivers. In Proceedings of the 2020 2nd International Conference on Management Science and Industrial Engineering, Osaka, Japan, 7-9 April 2020; pp. $253-260$.

69. Seo, S.E.; Tabei, F.; Park, S.J.; Askarian, B.; Kim, K.H.; Moallem, G.; Chong, J.W.; Kwon, O.S. Smartphone with optical, physical, and electrochemical nanobiosensors. J. Ind. Eng. Chem. 2019, 77, 1-11. [CrossRef]

70. Kotler, P. Behavioral models for analyzing buyers. J. Mark. 1965, 29, 37-45. [CrossRef]

71. Nicosia, F.M. Consumer Decision Processes; Marketing and Advertising Implications; Prentice-Hall: Englewood Cliffs, NJ, USA, 1966.

72. Ozanne, U.B.; Churchill, G.A., Jr. Five dimensions of the industrial adoption process. J. Mark. Res. 1971, 8, 322-328. [CrossRef]

73. Anderson, P.F.; Chambers, T.M. A reward/measurement model of organizational buying behavior. J. Mark. 1985, 49, 7-23. [CrossRef]

74. Wilson, E.J. Organizational buying in the quality revolution. Adv. Bus. Mark. Purch. 1994, 6, $33-58$.

75. Hofmaier, R. Marketing, Sales and Customer Management (MSC); De Gruyter Oldenbourg: Berlin, Germany, 2015.

76. Webster, F.E., Jr. Modeling the industrial buying process. J. Mark. Res. 1965, 2, 370-376. [CrossRef]

77. Robinson, P.J.; Faris, C.W.; Wind, Y. Industrial Buying and Creative Marketing; Allyn \& Bacon: Boston, MA, USA, 1967.

78. Holland, R.; Lam, B. Managing Strategic Design; Macmillan International Higher Education: London, UK, 2014.

79. O'Hern, M.S.; Rindfleisch, A. Customer co-creation: A typology and research agenda. In Review of Marketing Research; Routledge: Madison, WI, USA, 2017; pp. 84-106.

80. Kohtamäki, M.; Rajala, R. Theory and practice of value co-creation in B2B systems. Ind. Mark. Manag. 2016, 56, 4-13. [CrossRef]

81. Morgan, R.M.; Hunt, S.D. The commitment-trust theory of relationship marketing. J. Mark. 1994, 58, 20-38. [CrossRef]

82. Awa, H.O.; Ojiabo, O.U.; Emecheta, B.C. Integrating TAM, TPB and TOE frameworks and expanding their characteristic constructs for e-commerce adoption by SMEs. J. Sci. Technol. Policy Manag. 2015. [CrossRef]

83. Steward, M.D.; Narus, J.A.; Roehm, M.L.; Ritz, W. From transactions to journeys and beyond: The evolution of B2B buying process modeling. Ind. Mark. Manag. 2019, 83, 288-300. [CrossRef]

84. Blind, K. The impact of regulation on innovation. In Handbook of Innovation Policy Impact; Edward Elgar Publishing: Manchester, UK, 2016.

85. Aghion, P.; Bergeaud, A.; Van Reenen, J. The Impact of Regulation on Innovation; National Bureau of Economic Research: Cambridge, MA, USA, 2021.

86. Raj, A.; Dwivedi, G.; Sharma, A.; de Sousa Jabbour, A.B.L.; Rajak, S. Barriers to the adoption of industry 4.0 technologies in the manufacturing sector: An inter-country comparative perspective. Int. J. Prod. Econ. 2020, 224, 107546. [CrossRef]

87. Ehrlich, E.M.; Eisenach, J.A.; Leighton, W.A. The impact of regulation on innovation and choice in wireless communications. Rev. Netw. Econ. 2010, 9, 2. [CrossRef]

88. Davis, F.D. A Technology Acceptance Model for Empirically Testing New End-User Information Systems: Theory and Results; Massachusetts Institute of Technology: Cambridge, MA, USA, 1985.

89. Kemp, R. Technology and environmental policy: Innovation effects of past policies and suggestions for improvement. Innov. Environ. 2000, 1, 35-61.

90. Ćorić, D.S.; Anić, I.-D.; Rajh, S.P.; Rajh, E.; Kurnoga, N. Organizational buying decision approaches in manufacturing industry: Developing measures and typology. J. Bus. Ind. Mark. 2017. [CrossRef]

91. Chang, A.-M.; Kannan, P. Employee technology readiness and adoption of wireless technology and services. In Proceedings of the 39th Annual Hawaii International Conference on System Sciences (HICSS'06), Kauai, HI, USA, 4-7 January 2006; p. 42c.

92. Kohli, A. Determinants of influence in organizational buying: A contingency approach. J. Mark. 1989, 53, 50-65. [CrossRef]

93. Tornatzky, L.G.; Klein, K.J. Innovation characteristics and innovation adoption-implementation: A meta-analysis of findings. IEEE Trans. Eng. Manag. 1982, 29, 28-45. [CrossRef]

94. Hung, S.-Y.; Ku, C.-Y.; Chang, C.-M. Critical factors of WAP services adoption: An empirical study. Electron. Commer. Res. Appl. 2003, 2, 42-60. [CrossRef]

95. Wang, W.; Yuan, Y.; Wang, X.; Archer, N. RFID implementation issues in China: Shanghai port case study. J. Internet Commer. 2006, 5, 89-103. [CrossRef]

96. Hall, B.H.; Khan, B. Adoption of New Technology; NBER Working Papers 9730; National Bureau of Economic Research, Inc.: Cambridge, MA, USA, 2003. [CrossRef] 
97. Park, S.-W.; Lee, I.-Y. Efficient mCoupon authentication scheme for smart poster environments based on low-cost NFC. Int. J. Secur. Its Appl. 2013, 7, 131-138. [CrossRef]

98. Museli, A.; Navimipour, N.J. A model for examining the factors impacting the near field communication technology adoption in the organizations. Kybernetes 2018. [CrossRef]

99. Kim, D.J.; Ferrin, D.L.; Rao, H.R. A trust-based consumer decision-making model in electronic commerce: The role of trust, perceived risk, and their antecedents. Decis. Support Syst. 2008, 44, 544-564. [CrossRef]

100. Wamba, S.F.; Keating, B.W.; Coltman, T.; Michael, K. RFID Adoption Issues: Analysis of Organizational Benefits \& Risks; University of Wollongong: Wollongong, Australia, 2009.

101. Pham, T.-T.T.; Ho, J.C. The effects of product-related, personal-related factors and attractiveness of alternatives on consumer adoption of NFC-based mobile payments. Technol. Soc. 2015, 43, 159-172. [CrossRef]

102. Zhang, D.; Liu, Q. Biosensors and bioelectronics on smartphone for portable biochemical detection. Biosens. Bioelectron. 2016, 75, 273-284. [CrossRef] [PubMed]

103. Bolisetty, S.; Peydayesh, M.; Mezzenga, R. Sustainable technologies for water purification from heavy metals: Review and analysis. Chem. Soc. Rev. 2019, 48, 463-487. [CrossRef] [PubMed]

104. Kelly, J.P. Functions performed in industrial purchasing decisions with implications for marketing strategy. J. Bus. Res. 1974, 2, 421-434. [CrossRef]

105. Bradley, M. Buying behavior in Ireland's public sector. Ind. Mark. Manag. 1977, 6, 251-258. [CrossRef]

106. Ōmae, K.I. The Mind of the Strategist: The Art of Japanese Business; McGraw-Hill: New York, NY, USA, 1982.

107. Bunn, M.D. Key aspects of organizational buying: Conceptualization and measurement. J. Acad. Mark. Sci. 1994, 22, 160-169. [CrossRef]

108. Ghingold, M.; Wilson, D.T. Buying center research and business marketing practice: Meeting the challenge of dynamic marketing. J. Bus. Ind. Mark. 1998. [CrossRef]

109. Cohen, W.M.; Levinthal, D.A. Absorptive capacity: A new perspective on learning and innovation. Adm. Sci. Q. 1990, 35, 128-152. [CrossRef]

110. Cochran, W.G. Sampling Techniques; John Wiley \& Sons: Hoboken, NJ, USA, 2007.

111. Mariani, M.C.; Tweneboah, O.K.; Beccar-Varela, M.P. Data Science in Theory and Practice: Techniques for Big Data Analytics and Complex Data Sets; John Wiley \& Sons: Hoboken, NJ, USA, 2021.

112. Allen, M. Factor Analysis: Varimax Rotation. SAGE Encycl. Commun. Res. Methods 2017, 10, n191.

113. Hair, J.F.; Black, W.C.; Babin, B.J.; Anderson, R.E.; Tatham, R. Multivariate Data Analysis, 8th ed.; Cengage: Hampshire, UK, 2019.

114. Kaiser, H.F. An index of factorial simplicity. Psychometrika 1974, 39, 31-36. [CrossRef]

115. Bartlett, M.S. Properties of sufficiency and statistical tests. Proc. R. Soc. Lond. Ser. A Math. Phys. Sci. 1937, 160, $268-282$.

116. King, J.E. Binary logistic regression. Best Pract. Quant. Methods 2008, 20, 358-384.

117. Hutt, M.D.; Speh, T.W. Business Marketing Management: B2B; South-Western Cengage Learning: Mason, OH, USA, 2021.

118. Lee, J.; Qualls, W.J. A dynamic process of buyer-seller technology adoption. J. Bus. Ind. Mark. 2010. [CrossRef]

119. Linton, J.D.; Walsh, S.T. A theory of innovation for process-based innovations such as nanotechnology. Technol. Forecast. Soc. Chang. 2008, 75, 583-594. [CrossRef]

120. Barbu, A.; Militaru, G. Value co-creation between manufacturing companies and customers. The role of information technology competency. Procedia Manuf. 2019, 32, 1069-1076. [CrossRef]

121. Chiesa, V.; Frattini, F. Commercializing technological innovation: Learning from failures in high-tech markets. J. Prod. Innov. Manag. 2011, 28, 437-454. [CrossRef]

122. Katz, M.L.; Shapiro, C. Network externalities, competition, and compatibility. Am. Econ. Rev. 1985, 75, 424-440.

123. Thong, J.Y.; Yap, C.-S. CEO characteristics, organizational characteristics and information technology adoption in small businesses. Omega 1995, 23, 429-442. [CrossRef]

124. Petruzzelli, A.M.; Ardito, L.; Savino, T. Maturity of knowledge inputs and innovation value: The moderating effect of firm age and size. J. Bus. Res. 2018, 86, 190-201. [CrossRef]

125. Curtin, J.; Kauffman, R.J.; Riggins, F.J. Making the 'MOST'out of RFID technology: A research agenda for the study of the adoption, usage and impact of RFID. Inf. Technol. Manag. 2007, 8, 87. [CrossRef]

126. Fisher, J.A.; Monahan, T. Tracking the social dimensions of RFID systems in hospitals. Int. J. Med. Inform. 2008, 77, 176-183. [CrossRef]

127. Schaeffer, B.A.; Schaeffer, K.G.; Keith, D.; Lunetta, R.S.; Conmy, R.; Gould, R.W. Barriers to adopting satellite remote sensing for water quality management. Int. J. Remote Sens. 2013, 34, 7534-7544. [CrossRef]

128. Kuo, C.-H.; Chen, H.-G. The critical issues about deploying RFID in healthcare industry by service perspective. In Proceedings of the Proceedings of the 41st Annual Hawaii International Conference on System Sciences (HICSS 2008), Waikoloa, HI, USA, 7-10 January 2008; p. 111.

129. Bierman, P.; Lewis, M.; Ostendorf, B.; Tanner, J. A review of methods for analysing spatial and temporal patterns in coastal water quality. Ecol. Indic. 2011, 11, 103-114. [CrossRef]

130. Yao, W.; Chu, C.-H.; Li, Z. The adoption and implementation of RFID technologies in healthcare: A literature review. J. Med. Syst. 2012, 36, 3507-3525. [CrossRef] [PubMed] 
131. Han, T.-S.; Chiang, H.-H.; Chang, A. Employee participation in decision making, psychological ownership and knowledge sharing: Mediating role of organizational commitment in Taiwanese high-tech organizations. Int. J. Hum. Resour. Manag. 2010, 21, 2218-2233. [CrossRef]

132. Neubert, M.; Van Der Krogt, A.S. Decision-makers impact on the internationalization of high-technology firms in emerging markets. J. Glob. Entrep. Res. 2019, 9, 1-17. [CrossRef]

133. Dutot, V. Factors influencing near field communication (NFC) adoption: An extended TAM approach. J. High Technol. Manag. Res. 2015, 26, 45-57. [CrossRef]

134. Ting, S.; Kwok, S.K.; Tsang, A.H.; Lee, W.B. Critical elements and lessons learnt from the implementation of an RFID-enabled healthcare management system in a medical organization. J. Med. Syst. 2011, 35, 657-669. [CrossRef]

135. Chen, S.C.; Chen, H.H.; Chen, M.F. Determinants of satisfaction and continuance intention towards self-service technologies. Ind. Manag. Data Syst. 2009, 109, 1248-1263. [CrossRef]

136. Thailand-Hofstede Insights. Available online: https://www.hofstede-insights.com/country-comparison/thailand/ (accessed on 5 May 2021).

137. Moch, M.K.; Morse, E.V. Size, centralization and organizational adoption of innovations. Am. Sociol. Rev. 1977, 42, 716-725. [CrossRef]

138. Clarke, R. Internet privacy concerns confirm the case for intervention. Commun. ACM 1999, 42, 60-67. [CrossRef]

139. Swan, J.E.; Bowers, M.R.; Richardson, L.D. Customer trust in the salesperson: An integrative review and meta-analysis of the empirical literature. J. Bus. Res. 1999, 44, 93-107. [CrossRef]

140. Baker, N.R.; Sweeney, D.J. An Assessment of Modeling Capability Related to the Process of Organized Technological Innovation within the Firm; Department of Quantitative Analysis, College of Business Administration, University of Cincinnati: $\mathrm{Cincinnati,} \mathrm{OH}$, USA, 1978.

141. Anderson, P.; Tushman, M.L. Technological discontinuities and dominant designs: A cyclical model of technological change. Adm. Sci. Q. 1990, 35, 604-633. [CrossRef]

142. Shamkhalichenar, H.; Bueche, C.J.; Choi, J.-W. Printed Circuit Board (PCB) Technology for Electrochemical Sensors and Sensing Platforms. Biosensors 2020, 10, 159. [CrossRef] [PubMed]

143. Wasserstein, R.L.; Schirm, A.L.; Lazar, N.A. Moving to a World Beyond " $p<0.05$ ". Am. Stat. 2019, 73, 1-19. [CrossRef] 